\title{
ALTERNATIVES FOR EXITING THE LOSS ZONE FOR MEDIUM- SIZED AGRICULTURAL ENTERPRISES IN THE REPUBLIC OF SERBIA ${ }^{1}$
}

\author{
Sonja Đuričin ${ }^{2}$, Isidora Beraha ${ }^{3}$, Duško Bodroža ${ }^{4}$ \\ Summary
}

The research objective is to identify causes and alternatives for exiting the loss zone for agricultural enterprises in Serbia. The subject of the research is financial performance of agricultural enterprises in 2010-2014. Economic and financial power of all mediumsized agricultural enterprises was determined by applying financial analysis. Based on the sample of least successful entities, the causes and alternatives for exiting the loss zone were identified. The results show that loss appears due to a reduction in operating income or in contribution margin, or due to an increase in financial expenses. The first suggested alternative refers to increasing the volume of production and sales at current global price parity, while the second assumes shifting global price parity in favour of sales prices at current real capacity utilization rate. The effects of proposed alternatives are evaluated by two measures of profitability - return on assets and return on equity.

Key words: loss zone, agricultural enterprises, medium-sized enterprises, financial analysis, economic and financial power

JEL: $Q 12$

\section{Introduction}

The alternatives for exiting the loss zone are determined based on the evaluation of economic and financial power of agricultural enterprises in the period 2010-2014.

1 This study is a part of research projects No. 31005 (Modern Biotechnological Approach to Solving Problem of Drought in Agriculture of Serbia) and No. 47009 (European integrations and social and economic changes in Serbian economy on the way to the EU) financed by the Ministry of Education, Science and Technological Development of the Republic of Serbiafinanced by the Ministry of Science and Technological Development of the Republic of Serbia.

$2 \mathrm{PhD}$, Research Associate, Institute of Economic Sciences, 12 Zmaj Jovina Street, 11000 Belgrade, Republic of Serbia, Phone: +381 63843 8896, E-mail: sonja.djuricin@ien.bg.ac.rs

$3 \mathrm{PhD}$, Research Assistant, Institute of Economic Sciences, 12 Zmaj Jovina Street, 11000 Belgrade, Republic of Serbia, Phone: +381 64145 5955, E-mail: isidora.beraha@ien.bg.ac.rs

$4 \mathrm{PhD}$, Research Assistant, Institute of Economic Sciences, 12 Zmaj Jovina Street, 11000 Belgrade, Republic of Serbia, Phone: +381 64514 7136, E-mail: dusko.bodroza@ien.bg.ac.rs 
The focus is on medium-sized enterprises since they play a key role in economic development of the Republic of Serbia (RS). Although with a modest share in the overall structure of business enterprises and in the sector of small and medium-sized enterprises (SME), according to key developing indicators these enterprises represent the backbone of national economies (Erić, D. et al., 2012; Ivković, D. et al., 2012, pp. 31; Erić, D. et al., 2011, pp.70; Đuričin, S. et al., 2016).

According to the latest data from the National Bank of Serbia (NBS), medium-sized enterprises account for only $2 \%$ of total number of business entities in the Republic of Serbia, but generate $16 \%$ of total employment. Although they account for only $2 \%$ of the total number of enterprises, medium-sized enterprises generate $17 \%$ of revenues, $16 \%$ of the expenditures, $16 \%$ of total net income, and $14 \%$ of total net loss of all business entities in the country.

According to their share in key developing indicators of the SME sector, medium-sized enterprises account for only $0.7 \%$ of the total number of SMEs but generate $48 \%$ of total export, $40 \%$ of import, $29 \%$ of employment, $30 \%$ of turnover and $33 \%$ of GVA.

According to the Business Registers Agency's data for 2015, there were 1,004 mediumsized enterprises registered on the territory of the Republic of Serbia. Business entities registered in the sector A: Agriculture, forestry and fishing account for 7\% of the total number of medium-sized enterprises. The regional analysis pointed out to the uneven geographical distribution of medium-sized agricultural enterprises. Out of the total number of agricultural enterprises, $82 \%$ was registered on the territory of Vojvodina, $7 \%$ on the territory of South and East Serbia and on the territory of Sumadija and West Serbia, while only $4 \%$ was registered on the territory of Belgrade.

Out of the total number of agricultural enterprises registered on the territory of the Republic of Serbia in the period 2013-2014, 11\% recorded a net loss. Medium-sized enterprises which in the observed period of time operated with a net loss accounted for $19 \%$ of total employment of all enterprises of this size belonging to sector A: Agriculture, forestry and fishing. In the structure of medium-sized agricultural enterprises which in the period 2013-2014 recorded a net loss, entities registered on the territory of Vojvodina and Belgrade accounted for $75 \%$ and $25 \%$ respectively. Out of the total number of entities which recorded a net loss, $63 \%$ were engaged in crop production, while 37\% were engaged in stock-farming. In the 2013-2014 period of time, a net profit was recorded in medium-sized agricultural enterprises on the territory of South and East Serbia and on the territory of Sumadija and West Serbia.

The subject of the research was selected by considering the fact that $11 \%$ of the total number of observed enterprises which account for 19\% of total employment of medium-sized enterprises recorded a net loss in the period 2013-2014. The subject of the research refers to the financial performance of all agricultural enterprises. The objective of the research is to identify the alternatives for exiting the loss zone for those enterprises which in the period 2013-2014 recorded a net loss. For that reasons, the narrow and broad subject of the research is distinguished. The broad subject of 
the research refers to the period 2010-2014 when an economic and financial power of medium-sized agricultural enterprises was determined. The narrow subject of the research refers to the period 2013-2014 when the causes and alternatives for exiting the loss zone were identified.

The research begins with defining the hypothesis according to which implementation of suggested alternatives contributes to the higher profitability of enterprises. The effects of the proposed alternatives are evaluated by using two measures of profitability i.e. return on assets (ROA) and return on equity (ROE).

\section{Materials and methods}

In order to accomplish an overall research objective, the following methods were used: qualitative and quantitative financial analysis, common data collection and analysis methods, and description and synthesis methods (Đuričin, S. and Beraha, I., 2013, pp. 124; Neogradi, S., 2017, pp. 77).

By applying financial analysis (Đuričin, S. and Bodroža D., 2013, pp. 26; Mitrović, A. et al., 2015, pp. 1067; Majstorović, A. et al., 2016, pp. 1380) the economic and financial power of all medium-sized agricultural enterprises was determined. The analysis of economic and financial power of enterprises covered the period 2010-2014 which enabled the data comparability over time, as well as the notification of the dynamics movement of basic developing indicators. Financial analysis was conducted based on the information disclosed in the official financial statements of enterprises which are publically available on the Serbian Business Registers Agency web site. The subject of analysis is financial performance obtained from both summary and separate financial statements of medium-sized agricultural enterprises.

Considering that in the period 2010-2014 no stable trend in the number of enterprises ending a business year with net loss was determined, as well as that every year different enterprises recorded unprofitable operations, the research begun with identifying which enterprises and in what period of time showed a stable trend of operating with a net loss. The results indicate that a stable trend of operating with a net loss was observed only in the period 2013-2014. This way, the implementation of the common data collection and analysis methods (Đuričin, S. and Beraha, I., 2012; Petrović, P. and Vuković, D., 2016, pp. 1435) enabled narrowing the research subject which then referred only to 2013-2014 period of time.

Given that business is successful when a regular operating result is positive (Rodić, J et al., 2007; Đuričin, S, 2012), the enterprises which in the period 2013-2014 recorded a net loss as a result of regular operating activities were firstly identified by applying financial analysis method. Secondly, the causes of loss appearance were analysed for the previously identified enterprises. Accordingly, the main criterion for selecting the subject of research in the narrow sense refers to net loss from regular operating activities. Consequently, the further analysis includes only 8 enterprises out of which 3 enterprises are engaged in stock farming, while the other 5 are engaged in crop production. The 
causes of loss appearance from regular operating activities were determined based on the analysis of the relationship between global sales and purchasing price parity, the real capacity utilization rate and the efficiency of resource utilization (Rodić, J et al., 2007, pp. 217-222; Đuričin, S, 2012, pp. 165-170).

Further analysis aimed at identifying alternatives for exiting the loss zone was conducted only for those enterprises for which causes of unprofitable operation were adequately identified. An adequate identification of causes of unprofitable operation assumes that negative impact on financial result is greater than stated loss. Causes of unprofitable operation, as well as alternatives for exiting the loss zone were appropriately identified for 4 enterprises with equal representation of those engaged in stock farming and those engaged in crop production.

The elements that were formed by using the analysis method were then connected and brought into an interactive relationship by implementing the synthesis method (Đuričin, S. and Beraha, I., 2014, pp. 692; Savić, B. et al., 2014, pp. 1007). After a description was given on the determined relationship between the elements, conclusions were drawn about the possible solutions. The alternatives for exiting the loss zone were suggested for 4 enterprises for which the causes of non-profitable operation in the period 20132014 were adequately identified.

Suggested alternatives represent the unique economic method because the calculated value of financial performances, which was based on the data contained in separate financial statements, took into consideration all economic changes that occurred in observed enterprises, in observed period of time, and in the concrete sector. That also means that all specificities related to agricultural production which are relevant for agro-meteorological conditions, volatility in agricultural product prices/inputs, etc. which influenced economic changes in observed enterprises and were reflected in their separate financial statements were taken into consideration.

Through identified alternatives for exiting the loss zone, this research proposes a general solution for improving business performance. However, the implementation of suggested alternatives requires further analysis and individual approach to every single enterprise. This is primarily because agricultural production is rather specific comparing to other industries i.e. agricultural production is inflexible and its supply is both inelastic in the short term and dependent on weather conditions. Using an individual approach to every enterprise when selecting the most appropriate alternative or making the best combination of alternatives requires further analysis which would consider all specificities of agricultural production and carefully interpret profitability, yield and financial position assessment results.

Given that financial statements do not contain all the information necessary for identifying the causes of loss appearance (physical consumption of direct materials, labour and energy and services), the implementation of the identified alternatives had different impact on the profitability of analysed enterprises. In some cases it caused a reduction of negative rates of return, while in other enterprises it caused profitable 
operation. The effects of proposed alternatives are evaluated by using two measures of profitability i.e. return on assets (ROA) and return on equity (ROE).

Since general conclusions are made based on the research results, stating names of enterprises for which causes of loss were identified is avoided, while interpretation of final results considers all specificities of stock farming and corps production.

\section{Results}

In order to identify the objective of the research, the evaluation of economic and financial power of all medium-sized agricultural enterprises was conducted for the period 20102014. In the observed period of time, at the level of all medium-sized enterprises, a dominant share of operating income in total income amounting to an average of $94.79 \%$ was recorded. Operating income is largely burdened by operating expenses (an average burden of $86.08 \%$ ). At the level of all medium-sized agricultural enterprises, every Serbian Dinar (RSD) of operating income on average participated in the accumulation of $9.18 \%$ of operating profit and of $5.76 \%$ of net profit. Every RSD invested in total assets and equity gained on average $4.01 \%$ and $7.42 \%$ of net income respectively.

According to profitability ratios, in the period 2010-2014 the larger number of mediumsized agricultural enterprises operated with positive financial result. For that reasons, a positive net profitability effect at the level of summary balances of medium-sized agricultural enterprises was recorded. In the five-year period of time, the dynamics of the overall revenues and expenses of these enterprises resulted in the appearance of a positive gross financial result.

In $2010,12 \%$ of the total number of medium-sized agricultural enterprises operated with a net loss, while in the 2011-2012 period 5\% and 14\% respectively recorded a net loss. Only in the period 2013-2014, it was determined that the same enterprises operated with a net loss in both years. In the period 2013-2014, 11\% of the total number of medium-sized agricultural enterprises operated with a net loss.

The results of the analysis show that the loss appeared in the period 2013-2014 is a result of a reduction in operating income, a reduction in contribution margin and an increase in financial expenses. A reduction in the operating income occurred due to the worsening of global sales and purchasing price parity. A decline in the value of contribution margin appeared as a result of an insufficient real capacity utilization, while inefficient use of current assets increased the value of financial expenses.

A decline in operating income that appeared as a result of a worsening of global sales and purchasing price parity was detected in all medium-sized agricultural enterprises which in the period 2013-2014 operated with a loss. The enterprises recorded lower global price parity compared to its average value for the sector which in the period 2013-2014 amounted to 1.89 and 1.85 respectively.

The worsening of global price parity stipulated lower revenues than those that would have been gained in case the value of the parity remained at the sector average. The 
largest decline in the operating income that occurred as a result of a worsening of global price parity was recorded in enterprise number 4 in 2014, while the lowest was recorded in enterprise number 2 in 2013.

Table 1. Decline in operating income as a result of global parity worsening, - in 000 RSD -

\begin{tabular}{|c|c|c|c|c|c|c|}
\hline \multirow[t]{2}{*}{. } & \multirow[t]{2}{*}{ 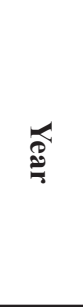 } & $\begin{array}{c}\text { Variable } \\
\text { material } \\
\text { costs }\end{array}$ & $\begin{array}{c}\text { Sector's } \\
\text { average } \\
\text { global } \\
\text { parity }\end{array}$ & $\begin{array}{c}\text { Operating } \\
\text { income } \\
\text { at } \\
\text { sector's } \\
\text { average } \\
\text { global } \\
\text { parity } \\
\end{array}$ & $\begin{array}{c}\text { Real } \\
\text { operating } \\
\text { income }\end{array}$ & $\begin{array}{l}\text { Decline in } \\
\text { operating } \\
\text { income due } \\
\text { to reduction } \\
\text { in global } \\
\text { parity }\end{array}$ \\
\hline & & 1. & 2. & 3. (1. x 2.) & 4. & 5. $(3 .-4)$. \\
\hline \multirow[t]{2}{*}{1} & 2013 & 741,700 & 1.89 & $1,401,812$ & $1,378,033$ & 23,779 \\
\hline & 2014 & 754,772 & 1.85 & $1,396,329$ & $1,384,959$ & 11,370 \\
\hline \multirow[t]{2}{*}{2} & 2013 & 578,219 & 1.89 & $1,092,835$ & $1,089,194$ & 3,641 \\
\hline & 2014 & 473,316 & 1.85 & 875,635 & 724,807 & 150,828 \\
\hline \multirow[t]{2}{*}{3} & 2013 & 588,379 & 1.89 & $1,112,036$ & 951.465 & 160,571 \\
\hline & 2014 & 458,276 & 1.85 & 847,810 & 679,309 & 168,501 \\
\hline \multirow[t]{2}{*}{4} & 2013 & 791,213 & 1.89 & $1,495,392$ & $1,120,124$ & 375,268 \\
\hline & 2014 & 810,386 & 1.85 & $1,499,214$ & $1,118,934$ & 380,280 \\
\hline \multirow[t]{2}{*}{5} & 2013 & 400,821 & 1.89 & 757,552 & 592,364 & 165,188 \\
\hline & 2014 & 269,237 & 1.85 & 498,089 & 416.285 & 81,804 \\
\hline \multirow[t]{2}{*}{6} & 2013 & 288,271 & 1.89 & 544,833 & 304,352 & 240,481 \\
\hline & 2014 & 290,024 & 1.85 & 536,544 & 386,363 & 150,181 \\
\hline \multirow[t]{2}{*}{7} & 2013 & 136,323 & 1.89 & 257,650 & 203,700 & 53,950 \\
\hline & 2014 & 98,598 & 1.85 & 182,406 & 136,285 & 46,121 \\
\hline \multirow[t]{2}{*}{8} & 2013 & 387,589 & 1.89 & 732,544 & 635,768 & 96,776 \\
\hline & 2014 & 345,107 & 1.85 & 638,448 & 577,681 & 60,767 \\
\hline
\end{tabular}

Source: Authors' calculation based on data obtained from official financial statements

A reduction in the contribution margin that occurred as a result of an insufficient real capacity utilisation was detected in all medium-sized enterprises which in the period 2013-2014 operated with a loss. In the period 2013-2014, the real capacity utilisation rate ranged between $45-98 \%$ which stipulated lower value of the contribution margin than it would have been recorded in case capacity utilisation was $100 \%$.

Significant differences in terms of an intensity of impact of insufficient real capacity utilisation on the value of contribution margin were observed by analysing data over time e.g. in enterprise number 2 the effects of insufficient real capacity utilisation were more than two times greater in 2013 comparing to 2014. The largest decline in the contribution margin due to an insufficient real capacity utilisation was recorded in enterprise number 2 in 2013, while the lowest was recorded in enterprise number 5 in 2014.

A loss recorded in the observed enterprises in the last two business years occurred also due to the inefficient current asset management. In order to determine the extent to 
which financial expenses increased because of an inefficient current asset management, an average turnover ratio at the sector level for the period 2013-2014 was identified. An increase in the value of financial expenses that appeared due to the inefficient current asset management was calculated by dividing current assets at an average turnover ratio by real current assets (Table 3 ).

Table 2. Decline in contribution margin due to insufficient real capacity utilisation, - in 000 RSD -

\begin{tabular}{|c|c|c|c|c|c|}
\hline \multirow{2}{*}{ 껄 } & \multirow[t]{2}{*}{ ๔્ఝ } & $\begin{array}{l}\text { Contribution } \\
\text { margin }\end{array}$ & $\begin{array}{l}\text { Real capacity } \\
\text { utilisation } \\
\text { rate }(\%)\end{array}$ & $\begin{array}{c}\text { Contribution margin } \\
\text { at } 100 \% \text { real capacity } \\
\text { utilisation }\end{array}$ & $\begin{array}{l}\text { Decline in contribution } \\
\text { margin due to } \\
\text { insufficient real capacity } \\
\text { utilisation }\end{array}$ \\
\hline & & 1. & 2. & 3. $(1 . / 2) \times 100$. & 4. $(3 .-1)$. \\
\hline \multirow[t]{2}{*}{1} & 2013 & 636,333 & 70 & 909,048 & 272,714 \\
\hline & 2014 & 630,187 & 70 & 900,267 & 270,080 \\
\hline \multirow[t]{2}{*}{2} & 2013 & 510,975 & 55 & 929,045 & 418,070 \\
\hline & 2014 & 251,491 & 55 & 457,256 & 205,765 \\
\hline \multirow[t]{2}{*}{3} & 2013 & 363,086 & 90 & 403,429 & 40,343 \\
\hline & 2014 & 221,033 & 90 & 245,592 & 24,559 \\
\hline \multirow[t]{2}{*}{4} & 2013 & 328,911 & 75 & 438,548 & 109,637 \\
\hline & 2014 & 308,548 & 75 & 411,398 & 102,849 \\
\hline \multirow[t]{2}{*}{5} & 2013 & 191,543 & 98 & 195,452 & 3,909 \\
\hline & 2014 & 147,048 & 98 & 150,049 & 3,001 \\
\hline \multirow[t]{2}{*}{6} & 2013 & 16,081 & 45 & 35,735 & 19,654 \\
\hline & 2014 & 96,339 & 45 & 214,087 & 117,748 \\
\hline \multirow[t]{2}{*}{7} & 2013 & 67,377 & 85 & 79,267 & 11,890 \\
\hline & 2014 & 37,687 & 85 & 44,338 & 6,651 \\
\hline \multirow[t]{2}{*}{8} & 2013 & 248,179 & 70 & 354,541 & 106,362 \\
\hline & 2014 & 232,574 & 70 & 332,249 & 99,675 \\
\hline
\end{tabular}

Source: Authors' calculation based on data obtained from official financial statements

Inefficient current asset management is typical only for certain enterprises i.e. enterprises which are determined to have positive difference between the value of real current asset and the value that would had been achieved in case an average turnover coefficient remained at the sector level.

An increase in the current asset value due to the inefficient management is present in enterprises number 2, 4, 6, and 7 in both business years, and in enterprise number 5 in 2014.

For enterprises in which an inefficient current asset management was identified, the amount of an increase in financial expenses was determined (Table 4).

The negative effects of inefficient current asset management are caused by the turnover ratio as well as by the level of indebtedness and the terms of obtaining external financing sources. 
Table 3. Increase in the value of current assets due to inefficient management, - in 000 RSD -

\begin{tabular}{|c|c|c|c|c|c|c|}
\hline \multirow[t]{2}{*}{. } & \multirow[t]{2}{*}{ ڤ్త } & $\begin{array}{l}\text { Operating } \\
\text { income }\end{array}$ & $\begin{array}{c}\text { Average } \\
\text { turnover } \\
\text { ratio } \\
\text { at } \\
\text { sector } \\
\text { level }\end{array}$ & $\begin{array}{c}\text { Current } \\
\text { assets } \\
\text { at } \\
\text { sector's } \\
\text { average } \\
\text { turnover } \\
\text { ratio }\end{array}$ & $\begin{array}{c}\text { Real } \\
\text { current } \\
\text { assets }\end{array}$ & $\begin{array}{c}\text { Increase in } \\
\text { current } \\
\text { assets } \\
\text { due to } \\
\text { decline in } \\
\text { turnover } \\
\text { ratio }\end{array}$ \\
\hline & & 1. & 2. & 3. (1./2.) & 4. & 5. (4.-3.) \\
\hline \multirow[t]{2}{*}{1} & 2013 & $1,378,033$ & 1.47 & 934,676 & 823,424 & $-111,252$ \\
\hline & 2014 & $1,384,959$ & 1.23 & $1,124,285$ & 751,572 & $-372,713$ \\
\hline \multirow[t]{2}{*}{2} & 2013 & $1,089,194$ & 1.47 & 738,766 & $1,114,923$ & 376,157 \\
\hline & 2014 & 724,807 & 1.23 & 588,385 & 684,742 & 96,357 \\
\hline \multirow[t]{2}{*}{3} & 2013 & 951,465 & 1.47 & 645,349 & 405,799 & $-239,550$ \\
\hline & 2014 & 679,309 & 1.23 & 551,451 & 459,639 & $-91,812$ \\
\hline \multirow[t]{2}{*}{4} & 2013 & $1,120,124$ & 1.47 & 759,745 & $1,491,488$ & 731,743 \\
\hline & 2014 & $1,118,934$ & 1.23 & 908,331 & $1,366,523$ & 458,192 \\
\hline \multirow[t]{2}{*}{5} & 2013 & 592,364 & 1.47 & 401,782 & 242,229 & $-159,553$ \\
\hline & 2014 & 416,285 & 1.23 & 337,933 & 398,409 & 60,476 \\
\hline \multirow[t]{2}{*}{6} & 2013 & 304,352 & 1.47 & 206,432 & $1,187,947$ & 981,515 \\
\hline & 2014 & 386,363 & 1.23 & 313,643 & $1,320,344$ & $1,006,701$ \\
\hline \multirow[t]{2}{*}{7} & 2013 & 203,700 & 1.47 & 138,163 & 156,189 & 18,026 \\
\hline & 2014 & 136,285 & 1.23 & 110,634 & 117,141 & 6,507 \\
\hline \multirow[t]{2}{*}{8} & 2013 & 635,768 & 1.47 & 431,221 & 239,056 & $-192,165$ \\
\hline & 2014 & 577,681 & 1.23 & 468,951 & 335,019 & $-133,932$ \\
\hline
\end{tabular}

Source: Authors' calculation based on data obtained from official financial statements

An increase in financial expenses due to inefficient current asset management is determined as a product of the value of an average interest rate and an increase in current assets caused by a decline in their turnover ratio. For the purpose of the calculation, an average interest rate is calculated as a ratio of financial expenses and liabilities causing interest rates payment.

The analysis results indicate that the greatest increase in financial expenses due to inefficient current asset management is recorded in enterprise number 6 , while the lowest is recorded in enterprise number 7. In case of enterprises number 1, 3 and 8 , in both business years, no increase in financial expenses was recorded. In enterprise number 5, an increase in financial expenses due to inefficient current asset management was recorded only in 2014. 
Table 4. Increase in financial expenses due to inefficient current asset utilisation, - in 000 RSD -

\begin{tabular}{|c|c|c|c|c|c|}
\hline \multirow[t]{2}{*}{. } & \multirow[t]{2}{*}{ ॠ } & $\begin{array}{c}\text { Financial } \\
\text { expenses }\end{array}$ & $\begin{array}{c}\text { Liabilities } \\
\text { causing } \\
\text { interest } \\
\text { rates } \\
\text { payment }\end{array}$ & $\begin{array}{c}\text { Average } \\
\text { interest } \\
\text { rate }\end{array}$ & $\begin{array}{c}\text { Possible } \\
\text { decline in } \\
\text { financial } \\
\text { expenses }\end{array}$ \\
\hline & & 1. & 2. & 3. $(1 . / 2) \times 100$. & 4. $\left(5^{*} \cdot x 3.\right) / 100$ \\
\hline \multirow[t]{2}{*}{1} & 2013 & 60,787 & 761,596 & 8 & $-8,880$ \\
\hline & 2014 & 79,003 & 729,403 & 11 & $-40,369$ \\
\hline \multirow[t]{2}{*}{2} & 2013 & 110,597 & 979,735 & 11 & 42,462 \\
\hline & 2014 & 144,703 & 703,474 & 21 & 19,820 \\
\hline \multirow[t]{2}{*}{3} & 2013 & 13,647 & 296,077 & 5 & $-11,042$ \\
\hline & 2014 & 23,974 & 390,381 & 6 & $-5,638$ \\
\hline \multirow[t]{2}{*}{4} & 2013 & 181,425 & $1,665,426$ & 11 & 79,713 \\
\hline & 2014 & 241,959 & $1,903,376$ & 13 & 58,246 \\
\hline \multirow[t]{2}{*}{5} & 2013 & 53,564 & 870,902 & 6 & $-9,813$ \\
\hline & 2014 & 51,747 & $1,004,658$ & 5 & 3,115 \\
\hline \multirow[t]{2}{*}{6} & 2013 & 339,498 & $2,025,018$ & 17 & 164,553 \\
\hline & 2014 & 271,006 & $2,095,649$ & 13 & 130,185 \\
\hline \multirow[t]{2}{*}{7} & 2013 & 13,278 & 381,567 & 3 & 627 \\
\hline & 2014 & 30,250 & 398,428 & 8 & 494 \\
\hline \multirow[t]{2}{*}{8} & 2013 & 41,618 & 686,689 & 6 & $-11,647$ \\
\hline & 2014 & 95,944 & 858,045 & 11 & $-14,976$ \\
\hline
\end{tabular}

Source: Authors' calculation based on data obtained from official financial statements Remark: * Number 5 is from Table 3

The total negative impact on financial results is illustrated in Table 5. A decline in the operating income due to global parity worsening, a decrease in the contribution margin due to the insufficient real capacity utilization and an increase in the financial expenses due to the inefficient current asset management are taken into consideration. In all enterprises in which the negative impact on financial result is greater than $100 \%$, a cause of the loss appearance is adequately identified.

Therefore, the causes of loss appearance in both business years are adequately identified in enterprises number 1, 3, 4 and 8 . Concerning enterprise number 2, the causes of loss appearance are adequately identified only in 2013, while concerning enterprises number 5 and 6 only in 2014. The causes of loss appearance were not adequately identified in either business year in enterprise number 7 .

Further analysis aimed at identifying the alternatives for exiting the loss zone is conducted only for those enterprises for which the causes of loss appearance are adequately identified in both business years i.e. in enterprises 1, 3, 4 and 8 . 
Along with an adequate financial performance based identification of the causes of loss, and before proposing alternatives, it is necessary to point out to some of the potential causes of unprofitable business which are specific to crop production and stock farming. Since crop production and stock farming are closely linked, the causes of loss from regular activities are also linked. The potential causes of loss appearance in stock farming, besides specific factors causing unprofitable operation, include all those elements that cause loss in crop production. This is mainly due to the fact that crop production presents the first level of agricultural production and is largely used for the development of the second level of agricultural production i.e. stock farming. One of the most common factors that caused loss certainly refers to drought that occurred in 2012 and whose consequences were felt in 2013 as well. The significant interdependence determined between the value of crop production yield and the meteorological movements points out to the low level of investments in the irrigation systems and to the large number of individual farms which are not capable of financing preventive measures and mechanisms of protection against drought thus limiting an extensive agricultural production (Vukelić, G and Đuričin, S, 2012). Besides extreme meteorological conditions, the loss also appears due to the fact that in the Republic of Serbia agricultural products with high production potentials are being imported, that the buyers of agricultural products hold a monopoly, and that there are significant oscillations in the volume and quality of production which along with existing external financing conditions resulted in bad price parity and put into question the self-financing of simple reproduction and survivor of agricultural enterprises (Ibid.).

Table 5. Examination of negative impact on financial results, - in 000 RSD -

\begin{tabular}{|c|c|c|c|c|c|c|c|}
\hline \multirow[t]{2}{*}{ 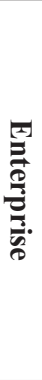 } & \multirow[t]{2}{*}{ 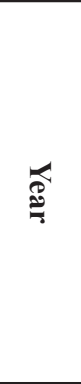 } & $\begin{array}{c}\text { Decline in } \\
\text { operating } \\
\text { income due } \\
\text { to } \\
\text { goglobal } \\
\text { price } \\
\text { parity } \\
\text { worsening }\end{array}$ & $\begin{array}{c}\text { Decline in } \\
\text { contribution } \\
\text { margine } \\
\text { due to } \\
\text { insufficient } \\
\text { real capacity } \\
\text { utilisation }\end{array}$ & $\begin{array}{c}\text { Increase in } \\
\text { financial } \\
\text { expensed } \\
\text { due to } \\
\text { inefficient } \\
\text { current } \\
\text { assets } \\
\text { utilisation }\end{array}$ & $\begin{array}{c}\text { Total } \\
\text { negative } \\
\text { impact on } \\
\text { financial } \\
\text { result }\end{array}$ & $\begin{array}{l}\text { Current } \\
\text { year loss }\end{array}$ & $\begin{array}{c}\text { Negative } \\
\text { impact on } \\
\text { financial } \\
\text { result } \\
\text { compared } \\
\text { with loss } \\
(\%)\end{array}$ \\
\hline & & 1. & 2. & 3. & 4. $(1 .+2 .+3)$. & 5. & $\begin{array}{l}\text { 6. (4./5.) } \\
\times 100\end{array}$ \\
\hline \multirow{2}{*}{1} & 2013 & 23,779 & 272,714 & 0 & 296,494 & 10,816 & 2,741 \\
\hline & 2014 & 11,370 & 270,080 & 0 & 281,450 & 47,148 & 597 \\
\hline \multirow{2}{*}{2} & 2013 & 3,641 & 418,070 & 42,462 & 464,173 & 51,461 & 902 \\
\hline & 2014 & 150,828 & 205,765 & 19,820 & 376,413 & 527,591 & 71 \\
\hline \multirow{2}{*}{3} & 2013 & 160,571 & 40,343 & 0 & 200,913 & 36,451 & 551 \\
\hline & 2014 & 168,501 & 24,559 & 0 & 193,060 & 110,477 & 175 \\
\hline \multirow{2}{*}{4} & 2013 & 375,268 & 109,637 & 79,713 & 564,618 & 369,782 & 153 \\
\hline & 2014 & 380,280 & 102,849 & 58,246 & 541,375 & 538,361 & 101 \\
\hline \multirow{2}{*}{5} & 2013 & 165,188 & 3,909 & 0 & 169,097 & 331,648 & 51 \\
\hline & 2014 & 81,804 & 3,001 & 3,115 & 87,920 & 80,941 & 109 \\
\hline
\end{tabular}




\begin{tabular}{|c|c|c|c|c|c|c|c|}
\hline \multirow{2}{*}{6} & 2013 & 240,481 & 19,654 & 164,553 & 424,688 & 944,713 & 45 \\
\cline { 2 - 8 } & 2014 & 150,181 & 117,748 & 130,185 & 398,114 & 305,209 & 130 \\
\hline \multirow{2}{*}{7} & 2013 & 53,950 & 11,890 & 627 & 66,468 & 237,906 & 28 \\
\cline { 2 - 8 } & 2014 & 46,121 & 6,651 & 494 & 53,266 & 57,655 & 92 \\
\hline \multirow{2}{*}{8} & 2013 & 96,776 & 106,362 & 0 & 203,138 & 76,793 & 265 \\
\cline { 2 - 8 } & 2014 & 60,767 & 99,675 & 0 & 160,441 & 112,857 & 142 \\
\hline
\end{tabular}

Source: Authors' calculation based on data obtained from official financial statements

The possibilities for exiting the loss zone are examined in terms of two alternatives. The first alternative refers to analyzing the possibilities of increasing the real capacity utilization i.e. increasing the volume of production and sales at the current global price parity. The second alternative refers to analyzing the possibilities of shifting the global price parity in favor of sales prices at current real capacity utilization rate i.e. current volume of production and sales. Two aspects of exiting the loss zone are analyzed for both alternatives. The first aspect assumes the corrections on the expenditure side, while the second aspect excludes those corrections. The analysis of the possibilities of exiting the loss zone by implementing the aforementioned two alternatives requires the consideration of the following assumptions:

- Real data on income is not corrected to higher values for the amount determined by analyzing the global price parity. An identified increase in expenses which could have occurred in case the worsening of global price parity did not appear is not taken into consideration since the research aims to determine the global price parity that is necessary in order to exit the loss zone.

- The achieved contribution margin is not corrected to higher value for the amount of decline determined based on underutilization of real capacity because the research aims to determine the real capacity utilization rate which is necessary in order for enterprises to exit the loss zone.

Table 6. Alternatives for exiting the loss zone, - in mil RSD -

\begin{tabular}{|c|c|c|c|c|c|c|c|c|c|}
\hline \multirow[t]{2}{*}{ No. } & \multirow{2}{*}{$\frac{\text { Enterprise }}{\text { Year }}$} & \multicolumn{2}{|c|}{1} & \multicolumn{2}{|c|}{3} & \multicolumn{2}{|c|}{4} & \multicolumn{2}{|c|}{8} \\
\hline & & 2013 & 2014 & 2013 & 2014 & 2013 & 2014 & 2013 & 2014 \\
\hline 1. & Operating income & 1.378 & 1.385 & 951 & 679 & 1.120 & 1.119 & 636 & 578 \\
\hline 2. & Variable expenses & 742 & 755 & 588 & 458 & 791 & 810 & 388 & 345 \\
\hline 3. & $\begin{array}{l}\mathrm{C} \text { o n tribu t i o } n \\
\text { margine }(\mathrm{CM})\end{array}$ & 636 & 630 & 363 & 221 & 329 & 309 & 248 & 233 \\
\hline 4.1 . & Fixed expenses & 494 & 503 & 392 & 306 & 527 & 540 & 258 & 230 \\
\hline 4.2 . & NFE* & 59 & 77 & 13 & 23 & 150 & 237 & 41 & 95 \\
\hline 4.3. & $\begin{array}{l}\text { Decline i NFE } \\
\text { due to inefficient } \\
\text { asset management }\end{array}$ & & & & & 80 & 58 & & \\
\hline 5. & $\begin{array}{l}\text { Share of CM } \\
\text { in operating income } \\
(3 / 1) \times 100\end{array}$ & $46 \%$ & $46 \%$ & $38 \%$ & $33 \%$ & $29 \%$ & $28 \%$ & $39 \%$ & $40 \%$ \\
\hline
\end{tabular}




\begin{tabular}{|c|c|c|c|c|c|c|c|c|c|}
\hline \multirow[t]{2}{*}{ No. } & \multirow{2}{*}{$\begin{array}{c}\text { Enterprise } \\
\text { Year }\end{array}$} & \multicolumn{2}{|c|}{1} & \multicolumn{2}{|c|}{3} & \multicolumn{2}{|c|}{4} & \multicolumn{2}{|c|}{8} \\
\hline & & 2013 & 2014 & 2013 & 2014 & 2013 & 2014 & 2013 & 2014 \\
\hline 6. & $\begin{array}{l}\text { Utilization } \\
\text { rate } \mathrm{RC}^{* *}\end{array}$ & $70 \%$ & $70 \%$ & $90 \%$ & $90 \%$ & $75 \%$ & $75 \%$ & $70 \%$ & $70 \%$ \\
\hline 7. & A & 1.199 & 1.276 & 1.062 & 1.010 & 2.308 & 2.817 & 767 & 808 \\
\hline 8. & $\mathrm{~B}$ & 554 & 1.276 & 1.062 & 1.010 & 2.308 & 2.817 & 767 & 808 \\
\hline $8 \mathrm{a}$ & $\mathrm{C}$ & & & & & 2.037 & 2.606 & & \\
\hline 9. & $\mathrm{D}$ & $46 \%$ & $100 \%$ & $100 \%$ & $100 \%$ & $100 \%$ & $100 \%$ & $100 \%$ & $100 \%$ \\
\hline $9 \mathrm{a}$ & $\mathrm{E}$ & & & & & $88 \%$ & $93 \%$ & & \\
\hline 10. & $\mathrm{~F}$ & $-60 \%$ & $-8 \%$ & $12 \%$ & $49 \%$ & $106 \%$ & $152 \%$ & $21 \%$ & $40 \%$ \\
\hline $10 \mathrm{a}$ & $\mathrm{G}$ & & & & & $82 \%$ & $133 \%$ & & \\
\hline 11. & $\mathrm{H}$ & $-6 \%$ & $-4 \%$ & $4 \%$ & $16 \%$ & $31 \%$ & $42 \%$ & $8 \%$ & $16 \%$ \\
\hline $11 \mathrm{a}$ & I & & & & & $11 \%$ & $5 \%$ & & \\
\hline \multicolumn{10}{|c|}{$\begin{array}{l}* \text { Net financing expenses; **Real capacity; } * * * \text { Neutral result; } * * * * \text { Global price parity; WC- } \\
\text { without correction; WIC - with correction; A - Income at } 100 \% \text { RC }(1 / 6) \times 100 \text {; Volume of } \\
\text { production and sales for achieving NR WC }((4.1 .+4.2 .) / 5) \times 100 ; \mathrm{C}-\text { Volume of production and } \\
\text { sales for achieving NR WIC }((4.1 .+(4.2 .-4.3 .)) / 5 .) \times 100 ; \mathrm{D}-\mathrm{RC} \text { for achieving NR at current GPP } \\
\text { WC }(8 / 7) \times 100 \text {; E - RC for achieving NR at current GPP WIC }(8 \mathrm{a} / 7) \times 100 ; \mathrm{F}-\text { Increase in volume } \\
\text { of production and for achieving NR at current GPP } \\
\text { WC }((8-1) / 1) \times 100 \text {; G - Increase in volume of production and for achieving NR at current GPP } \\
\text { WIC }((8 \mathrm{a}-1) / 1) \times 100 \text {; H - \% change GP for achieving NR at current RC WC }(((4.1 .+4.2 .)-3 .) / 1 .) \\
x 100 \text {; I - } \% \text { change GP for achieving NR at current RC WIC }((4.1 .-(4.2 .-4.3 .))-3 .) / 1 .) \times 100\end{array}$} \\
\hline
\end{tabular}

Source: Authors' calculation based on data obtained from official financial statements

In accordance with the research results and given assumptions, both alternatives in terms of both aspects are analysed only for enterprise number 4 . This is because only in case of enterprise number 4 it is possible to correct the net financing expenses to lower values due to the inefficient current asset management. In case of all other enterprises which in the period 2013-2014 operated with a loss, i.e. in case of enterprises number 1, 3 and 8 the above average efficiency of current asset management which has no impact on increase in financial expenses is determined. The alternatives for exiting the loss zone for each enterprise in the period 2013-2014 are the following:

- Enterprise number 1 can achieve a neutral financial result at the current global parity of sales and purchasing prices by decreasing the volume of production and sales which assumes the real capacity utilization rate of $46 \%$ and $100 \%$ respectively. Also, this alternative assumes a reduction of $60 \%$ and $8 \%$ respectively in the physical volume of production and sales. A neutral financial result at the existing volume of production and sales can be achieved by enterprise number 1 only if the global parity of sales and purchasing prices shifts in favour of purchasing prices by $6 \%$ and $4 \%$ respectively.

- Enterprise number 3 can achieve a neutral financial result at the current global parity of sales and purchasing prices by increasing the volume of production and sales which assumes the real capacity utilization rate of $100 \%$ and an increase of $12 \%$ and $49 \%$ respectively in the physical volume of production and 
sales. A neutral financial result at the existing volume of production and sales can be achieved by enterprise number 3 only if the global parity of sales and purchasing prices shifts in favour of sales prices by $4 \%$ and $16 \%$ respectively.

- Enterprise number 4 can achieve a neutral financial result at the current global parity of sales and purchasing prices by increasing the volume of production and sales which assumes the real capacity utilization rate of $100 \%$ in case no correction of expenses is made i.e. $88 \%$ and $93 \%$ respectively in case the correction of expenses is made. The first alternative requires that the physical volume of production and sales increases up to $106 \%$ and $152 \%$ respectively in comparison with the existing volumes, and the second alternative requires an increase of $82 \%$ and $133 \%$ respectively. A neutral financial result at the existing volume of production and sales can be achieved by enterprise number 4 only if the global parity of sales and purchasing prices shifts in favour of sales prices by $31 \%$ and $42 \%$ respectively in case of first alternative i.e. by $11 \%$ and $5 \%$ respectively in case of second alternative.

- Enterprise number 8 can achieve a neutral financial result at the current global parity of sales and purchasing prices by increasing the volume of production and sales which assumes the real capacity utilization rate of $100 \%$ and an increase of $21 \%$ and $40 \%$ respectively in the physical volume of production and sales. A neutral financial result at the existing volume of production and sales can be achieved by enterprise number 8 only if the global parity of sales and purchasing prices shifts in favour of sales prices by $8 \%$ and $16 \%$ respectively.

In order to exit the loss zone, enterprises will choose the alternative that is possible to implement at the given moment in time or will decide to combine certain elements from both alternatives. The elements from both alternatives are to be combined in case a question is raised regarding the amount of global price parity at the real capacity utilization rate of $100 \%$.

Table 7. Changes in global price parity at $100 \%$ real capacity utilization rate, - in mil RSD -

\begin{tabular}{|c|l|c|c|c|c|c|c|c|c|}
\hline \multirow{2}{*}{ No. } & \multicolumn{1}{|c|}{ Enterprise } & \multicolumn{2}{|c|}{$\mathbf{1}$} & \multicolumn{2}{c|}{$\mathbf{3}$} & \multicolumn{2}{|c|}{$\mathbf{4}$} & \multicolumn{2}{|c|}{$\mathbf{8}$} \\
\cline { 2 - 11 } & Year & $\mathbf{2 0 1 3}$ & $\mathbf{2 0 1 4}$ & $\mathbf{2 0 1 3}$ & $\mathbf{2 0 1 4}$ & $\mathbf{2 0 1 3}$ & $\mathbf{2 0 1 4}$ & $\mathbf{2 0 1 3}$ & $\mathbf{2 0 1 4}$ \\
\hline 1. & Operating income & 1,378 & 1,385 & 951 & 679 & 1,120 & 1,119 & 636 & 578 \\
\hline 2. & Variable expenses & 742 & 755 & 588 & 458 & 791 & 810 & 388 & 345 \\
\hline 3. & RC utilization & $70 \%$ & $70 \%$ & $90 \%$ & $90 \%$ & $75 \%$ & $75 \%$ & $70 \%$ & $70 \%$ \\
\hline 4. & $\begin{array}{l}\text { Operating income at } \\
\begin{array}{l}100 \% \\
\text { RC (1./3.)x100 }\end{array}\end{array}$ & 1,969 & 1,979 & 1,057 & 755 & 1,493 & 1,492 & 908 & 825 \\
\hline 5. & $\begin{array}{l}\text { Variable expenses } \\
\text { at } 100 \% \text { RC } \\
(2 . / 3 .) \times 100\end{array}$ & 1,060 & 1,078 & 654 & 509 & 1,055 & 1,081 & 554 & 493 \\
\hline
\end{tabular}




\begin{tabular}{|c|l|c|c|c|c|c|c|c|c|}
\hline \multirow{2}{*}{ No. } & \multicolumn{1}{|c|}{ Enterprise } & \multicolumn{2}{|c|}{$\mathbf{1}$} & \multicolumn{2}{c|}{$\mathbf{3}$} & \multicolumn{2}{|c|}{$\mathbf{4}$} & \multicolumn{2}{|c|}{$\mathbf{8}$} \\
\cline { 2 - 10 } Year & $\begin{array}{l}\text { Contribution margine } \\
\text { at 100\% RC } \\
(4 .-5 .)\end{array}$ & 909 & 900 & 403 & 246 & 439 & 411 & 355 & 332 \\
\hline 7. & $\begin{array}{l}\text { Fixed expenses and } \\
\text { Net financing expenses }\end{array}$ & 554 & 581 & 405 & 329 & 678 & 777 & 299 & 325 \\
\hline 8. & $\begin{array}{l}\text { \% change of GPP } \\
\text { In favor of sales prices } \\
\text { at 100\% } \\
\text { RC utilization } \\
((7 .-6 .) / 4 .) \times 100\end{array}$ & -18.04 & -16.16 & 0.17 & 10.99 & 16.02 & 24.50 & -6.08 & -0.85 \\
\hline
\end{tabular}

Source: Authors' calculation based on data obtained from official financial statements

In the period 2013-2014, in order to achieve a neutral financial result at the real capacity utilization rate of $100 \%$ :

- enterprise number 1 can reduce the sales price by $18.04 \%$ and $16.16 \%$ respectively;

- enterprise number 3 should increase the sales price by 0.17 and $10.99 \%$ respectively;

- enterprise number 4 should increase the sales price by $16.02 \%$ and $24.50 \%$ respectively, and

- enterprise number 8 can decrease the sales price by $6.08 \%$ and $0.85 \%$ respectively.

After results of the analysis are being presented, the production, purchasing and sales experts decide on the alternative for exiting the loss zone. The selected alternative or combination of elements of various alternatives must be the realistically feasible one. When deciding on the suitable alternative, the experts have to consider all technical and natural limitations, as well as limitations of the sales and purchasing markets. After an appropriate alternative is selected, the plan for exiting the loss zone is being prepared and presented to the management of the company. Due to the specificity of agricultural production, when selecting the most appropriate alterative it is necessary to perceive the impact of their implementation on the value of financial performance used to measure business success. For example, when selecting the most suitable alternative or the combination of alternatives and when examining the impact of their implementation on the efficiency of current asset management it is necessary to consider that agricultural enterprises are specific in terms of production cycle and product redemption. Also, when assessing the impact of selected alternative on business profitability it is necessary to consider specificities of product range of concrete agricultural enterprise. This is mainly due to the fact that sales of finished products is the most important profit category and it is highly influenced by the flexibility of inventory storage and the possibility of its realisation when the best market price occurs. 
Since achieving neutral financial result is never a company's overall objective, the management decides on the alternative which will enable higher profits in the following accounting periods.

\section{Discussion}

Inferior global price parity in the agricultural production of the Republic of Serbia has been a significant problem for over decades (Vukelić, G and Đuričin, S, 2012). Such price parity is mainly a result of the monopoly positions of large buyers of agricultural products, import of products for whose production the Republic of Serbia is highly potential and large oscillations in the production volume and quality. The inferior price parity is reflected in poor input purchasing mechanism and final agricultural product sales. According to the existing mechanism, the purchasing price is defined in Serbian dinars, while the input prices are given in Euro. At the same time, due to cash shortages, the producers often use barter trade to acquire necessary inputs thus suffering huge losses. A decline in operating income due to global price parity worsening at current external financing market conditions stipulates the absence of simple reproduction renewal ability, inferior technical facilities and high percentage of representation of outdated machinery (Bubić, J. and Hajnrih, J, 2012).

Improving market chain in the agricultural production and establishing efficient price parity mechanism would stipulate positive effects for individual producers, as well as for the entire sector and state through increased budget revenues. The first step in market chain improvement refferes to establishing a productive input acquiring and production support mechanism. A productive mechanism assumes monopoly suppression in input market, mainatining quality control systems for inputs and final products, maintaining a system in which input prices are in line with final product price movement, subsidizing input purchasing and renewal of oudated depending on the preveious returns, etc.

Insufficient real capacity utilization is determined in all analysed enterprises. This implies that the use of fixed assets is irrational. A decrease in real capacity i.e. in the possibility of using the built-in capacity in most cases is due to worsening conditions for business processes. These conditions mainly refer to the quantity and quality of productive output, production requisites and their characteristics, labour force and its professional competence, level of organization, technology procedures, etc. In case of analysed enterprises, the insufficient real capacity utilization, under the impact of fixed costs, stipulates the need for an increase in the cost price. Since the market conditions did not allow the cost price growth, a decrease in the value of financial result and profitability of the analysed enterprises occurred.

Inefficient current asset management stipulated the growth of financial expenses only in case of enterprise number 4. Consequently, the positive effects of implementation of identified alternatives were examined only in terms of absence of expenses corrections. The effects of implementation of both alternatives are determined based on the value of profitability performance ROA and ROE. Impossibility of using accounting data 
for the purpose of determining the effects of physical consumption of direct material, labour, energy and services on unprofitable operation caused improved profitability of all enterprises but not the complete removal of negative result. In case of enterprises where the value of ROA and ROE improved but the loss remained, it is necessary to implement the suggested alternatives in several consecutive accounting periods. The continuous implementation of suggested alternatives along with the constant examination of provided effects and adjustment of parameters would enable exiting the loss zone as well as entering into the positive financial results zone.

Table 8. Effects of implementation of suggested alternatives for exiting the loss zone

\begin{tabular}{|l|r|r|r|r|r|r|r|r|}
\hline \multirow{2}{*}{ Position } & \multicolumn{2}{|c|}{ Enterprise } & \multicolumn{2}{c|}{ Enterprise } & \multicolumn{2}{c|}{ Enterprise } & \multicolumn{2}{c|}{ Enterprise } \\
\cline { 2 - 9 } & 2013 & 2014 & 2013 & 2014 & 2013 & 2014 & 2013 & 2014 \\
\hline $\begin{array}{l}\text { ROA before the } \\
\text { alternatives } \\
\text { implementation }\end{array}$ & -0.79 & -3.70 & -4.76 & -14.18 & -9.46 & -14.40 & -2.29 & -3.24 \\
\hline $\begin{array}{l}\text { ROA after } \\
\text { increase in } \\
\text { production } \\
\text { and sales }\end{array}$ & -0.32 & -3.40 & -4.19 & -7.23 & $\mathbf{0 . 5 7}$ & $\mathbf{7 . 4 9}$ & -1.81 & -1.94 \\
\hline $\begin{array}{l}\text { ROA after } \\
\text { change in } \\
\text { global price parity }\end{array}$ & -0.74 & -3.55 & -4.57 & -11.91 & -6.52 & -8.35 & -2.11 & -2.72 \\
\hline $\begin{array}{l}\text { ROE before the } \\
\text { alternatives } \\
\text { implementation }\end{array}$ & -3.85 & -20.17 & -10.65 & -49.85 & -24.21 & -52.93 & -3.23 & -4.99 \\
\hline $\begin{array}{l}\text { ROE after increase } \\
\text { in production and } \\
\text { sales }\end{array}$ & -1.54 & -18.55 & -9.37 & -25.42 & $\mathbf{1 . 4 5}$ & $\mathbf{2 7 . 5 3}$ & -2.56 & -2.99 \\
\hline $\begin{array}{l}\text { ROE after } \\
\text { change in } \\
\text { global price parity }\end{array}$ & -3.62 & -19.36 & -10.22 & -41.88 & -16.71 & -30.70 & -2.98 & -4.19 \\
\hline
\end{tabular}

Source: Authors'calculation based on data obtained from official financial statements

Alternative $\mathbf{1}$ - in the 2013-2014 period of time after the implementation of the alternative which assumes the growth of production and sales at the current global price parity, the following effect was recorded:

- Instead of realizing $0.79 \%$ and $3.70 \%$ of net loss respectively on every RSD invested in total assets, enterprise number 1 realizes $0.32 \%$ and $3.40 \%$ of net loss respectively. Instead of realizing $3.85 \%$ and $20.17 \%$ of net loss respectively on every RSD invested in equity, enterprise number 1 realizes $1.54 \%$ and $18.55 \%$ of net loss respectively;

- Instead of realizing $4.76 \%$ and $14.18 \%$ of net loss respectively on every RSD invested in total assets, enterprise number 3 realized $4.19 \%$ and $7.23 \%$ of net loss respectively. Instead of realizing $10.65 \%$ and $49.85 \%$ of net loss respectively on every RSD invested in equity, enterprise number 3 realizes $9.37 \%$ and $25.42 \%$ of net loss respectively; 
- Instead of realizing $9.46 \%$ and $14.40 \%$ of net loss respectively on every RSD invested in total assets, enterprise number 4 realizes $0.57 \%$ and $7.49 \%$ of net income respectively. Instead of realizing $24.21 \%$ and $52.93 \%$ of net loss respectively on every RSD invested in equity, enterprise number 4 realizes $1.45 \%$ and $27.53 \%$ of net income respectively;

- Instead of realizing $2.29 \%$ and $3.24 \%$ of net loss respectively on every RSD invested in total assets, enterprise number 8 realizes $1.81 \%$ and $1.94 \%$ of net loss respectively. Instead of realizing $3.23 \%$ and $4.99 \%$ of net loss respectively on every RSD invested in equity, enterprise number 8 realizes $2.56 \%$ and $2.99 \%$ of net loss respectively.

Alternative 2 - in the period 2013-2014 after the implementation of the alternative which assumes the change of the global price parity at the current volume of production and sales, the following effect was recorded:

- Instead of realizing $0.79 \%$ and $3.70 \%$ of net loss respectively on every RSD invested in total assets, enterprise number 1 realizes $0.74 \%$ and $3.55 \%$ of net loss respectively. Instead of realizing $3.85 \%$ and $20.17 \%$ of net loss respectively on every RSD invested in equity, enterprise number 1 realizes 3.62\% and 19.36\% of net loss respectively;

- Instead of realizing $4.76 \%$ and $14.18 \%$ of net loss respectively on every RSD invested in total assets, enterprise number 3 realizes $4.57 \%$ and $11.91 \%$ of net loss respectively. Instead of realizing $10.65 \%$ and $49.85 \%$ of net loss respectively on every RSD invested in total assets, enterprise number 3 realizes $10.22 \%$ and $41.88 \%$ of net loss respectively;

- Instead of realizing $9.46 \%$ and $14.40 \%$ of net loss respectively on every RSD invested in total assets, enterprise number 4 realizes $6.52 \%$ and $8.35 \%$ of net loss respectively. Instead of realizing $24.21 \%$ and $52.93 \%$ of net loss respectively on every RSD invested in equity, enterprise number 4 realizes $16.71 \%$ and $30.70 \%$ of net loss respectively;

- Instead of realizing $2.29 \%$ and $3.24 \%$ of net loss respectively on every RSD invested in total assets, enterprise number 8 realizes $2.11 \%$ and $2.72 \%$ of net loss respectively. Instead of realizing $3.23 \%$ and $4.99 \%$ of net loss respectively on every RSD invested in equity, enterprise number 8 realizes $2.98 \%$ and $4.19 \%$ of net loss respectively.

The research results indicate that the implementation of both alternatives has positive effects on the profitability of enterprises. In case of the implementation of the first alternative, better operating results are recorded in all analysed enterprises. In case of the implementation of the second alternative, enterprise number 4 would exit the loss zone and enter the zone of positive financial results and profitable operation. 


\section{Conclusion}

The main objective of the paper which refers to the identification of causes and alternatives for exiting the loss zone for agricultural enterprises registered on the territory of the Republic of Serbia is completely accomplished by the conducted research. The research results showed that the loss recorded in the 2013-2014 period of time occurred as a result of a decrease in operating income, decline in contribution margin and increase in financial expenses. A decrease in operating income was caused by the worsening of global parity of sales and purchasing prices. The value of contribution margin decreased as a result of insufficient real capacity utilization, while the recorded growth of financial expenses was due to inefficient utilization of current assets.

In order to exit the loss zone, two alternatives are suggested. The first alternative refers to the analysis of possibilities for increasing the volume of production and sales at the current global price parity, while the second alternative assumes the analysis of the possibilities for shifting the global price parity in favour of sales prices at the current rate of real capacity utilization i.e. current volume of production and sale.

The research results point out to the positive effects of the implementation of both alternatives for exiting the loss zone. In the majority of enterprises, the implementation of both alternatives causes the decrease and not the complete absence of negative profitability indicators. Neutralizing non-profitable operation and entering the zone of neutral and afterwards the zone of positive operating results requires the implementation of suggested alternatives in a number of consecutive accounting periods.

The first alternative which assumes the growth of production and sales at the current global price parity gave better results in all analysed enterprises. In case of enterprise number 4 , the implementation of this alternative caused exiting from non-profitable and entering profitable operation zone. In enterprises in which this alternative caused a decrease in negative profitability rates, an introduction of a larger number of jobs is recommended in order to increase the real capacity utilisation and further growth of production and sales.

The research results confirmed the hypothesis according to which the implementation of suggested alternatives contributes to higher profitability of enterprises. Besides the effects on individual enterprises, the implementation of alternatives has the wider social impact as well. Through higher profitability of enterprises, it indirectly leads to higher profitability of sectors and the economy as a whole. Strengthening mediumsized agricultural enterprises contributes to greater employment of the workforce and its more significant participation in the key macroeconomic indicators.

Individual and in-depth analysis aimed at selecting one of suggested alternatives requires evaluation of all specificities of crop production in case of enterprises number 3 and 4, and of stock farming in case of enterprises number 1 and 8. For example, if examining the impact of implementation of the certain alternative on profitability it is necessary to consider the values of ROA and ROE, but also the ownership structure of financing, solvency of operation, etc. 


\section{References}

1. Bubić, J. and Hajnrih, J. (2012). The analyses business performances of agricultural enterprises in Vojvodina during the current crisis. Economics of Agriculture, The Balkan Scientific Association of Agrarian Economists, Institute of Agricultural Economics, Belgrade and Academy of Economic Studies , 2012 (Vol. 59, No. 2), pp. 183-195.

2. Đuričin, S. (2012). Analiza poslovanja i mogućnosti izlaska preduzeća iz zone gubitka (ISBN: 978-86-80315-92-8). Institut ekonomskih nauka, Beograd.

3. Đuričin, S. and Beraha I. (2012). Promoting availability of financing to SMEs in Serbia on the road to EU integration, European integration process in Western Balkan countries (ISBN: 978-972-9344-05-3). Faculty of Economics of the University of Coimbra, pp. 493-511. Coimbra, Portugal.

4. Đuričin, S. and Beraha, I. (2013). Evaluation of Business Performances of Agricultural Enterprises in the Mixed Farming Sub-sector and their Impact on Economic Growth of the Republic of Serbia. Agriculture in Serbia and Portugal: recent developments and economic policy implications, Faculty of Economics of the University of Coimbra, 2013, pp. 122-138, Coimbra, Portugal.

5. Đuričin, S. and Bodroža D. (2013). The impact of drought on yield position of the group of enterprises from agriculture sector. Economics of agriculture, The Balkan Scientific Association of Agrarian Economists, Institute of Agricultural Economics, Belgrade and Academy of Economic Studies, 2013 (Vol. LX, No.1), pp. 25-39, Bucharest, Romania.

6. Đuričin, S. i Beraha I. (2014) Unapređenje finansijskih performansi agroindustrijskog sektora po osnovu podsticajnih mera razvoja (ISBN; 978-8689465-12-9). Deindustrijalizacija u Srbiji, Institut ekonomskih nauka, Beogradska bankarska akademija, Fakultet za bankarstvo, osiguranje i finansije, pp. 690-703, Beograd.

7. Đuričin, S., Stevanović, S., Ljumović, I., and Simović, V. (2016) Nacionalna mreža srednjih preduzeća u Republici Srbiji, (ISSN: 2466-5274). Institute of economic sciences, Belgrade

8. Erić, D., Beraha, I. and Đuričin, S. (2011) Financing innovative small and mediumsized enterprises in times of crisis, Revista Romana de Economie: Romanian Journal of Economics, 2011, pp. 59-74, Romanian Academy.

9. Erić, D., Beraha, I., Đuričin, S., Kecman, N. and Jakišić, B. (2012). Finansiranje malih i srednjih preduzeća u Srbiji, (ISBN: 978-86-80315-94-2). Privredna komora Srbije, Institut ekonomskih nauka, Beograd.

10. Ivković, D., Karavidić, Č, M., and Vujićić, S. (2012). Small and Medium-Sized Enterprises as a Factor of Serbian Economy. Economic Analysis. Institute of economic sciences, 2012 (Vol 45/No 3-4), pp. 31-45, Belgrade, Serbia

11. Majstorović, A., Miloradić, J., Andžić, S., Andžić, R., Divac, G., Aničić, A., and 
Mirković, Z. (2016). Legal aspects of financial analysis in agribusiness companies in Serbia. Economics of agriculture, The Balkan Scientific Association of Agrarian Economists, Institute of Agricultural Economics, Belgrade and Academy of Economic Studies, 2016 (63/ No.4), pp. 1379-1393, Bucharest, Romania.

12. Mitrović, A., Knežević, S. and Veličković, M. (2014). Ratio analysis specifics of the family dairies' financial statements. Economics of agriculture, The Balkan Scientific Association of Agrarian Economists, Institute of Agricultural Economics, Belgrade and Academy of Economic Studies, 2015 (62/ No.4), pp. 1061-1078, Bucharest, Romania.

13. National Bank of Serbia, Basic macroeconomic indicators, available at: https:// www.nbs.rs/internet/cirilica/80/index.html (date: 05/09/2017.)

14. Neogradi, S. (2017). Methodology of Credit Analysis Development. Economic Analysis, Institute of economic sciences, 2013, Vol 50, No. 3-4, pp.75-85, Belgrade, Republic of Serbia.

15. Petrović, P. and Vuković, D. (2016). Financial sources of small and medium enterprises for agribusiness and eco-tourism in Serbia. Economics of agriculture, The Balkan Scientific Association of Agrarian Economists, Institute of Agricultural Economics, Belgrade and Academy of Economic Studies, 2016 (63/ No.4), pp. 1433-1444, Bucharest, Romania.

16. Rodić, J. Vukelić, G. i Andrić, M. (2007). Teorija, politika i analiza bilansa (ISBN: 978-86-7834-040-6). Poljoprivredni fakultet, Beograd.

17. Savić, B., Vasiljević, Z. and Đorđević, D. (2014). Strategic cost management as instrument for improving competitiveness of agribusiness complex. Economics of agriculture, The Balkan Scientific Association of Agrarian Economists, Institute of Agricultural Economics, Belgrade and Academy of Economic Studies, 2014 (61/ No.4), pp. 1005-1022, Bucharest, Romania.

18. Serbian Business Registers Agency, Financial Statements, available at: http:// pretraga2.apr.gov.rs/ObjedinjenePretrage/Search/Search (date: 05/06/2017.)

19. Vukelić, G. and Đuričin, S. (2012). Agricultural Output Growth at the Regional Level in Serbia. Managing structural changes: trends and requirements (ISBN: 978972-9344-06-0). Faculty of Economics of the University of Coimbra, pp. 611-626. 


\title{
ALTERNATIVE ZA IZLAZAK IZ ZONE GUBITKA SREDNJIH POLJOPRIVREDNIH PREDUZEĆA U REPUBLICI SRBIJI
}

\author{
Sonja Đuričin ${ }^{5}$, Isidora Beraha ${ }^{6}$, Duško Bodroža
}

\begin{abstract}
Sažetak
Cilj istraživanja je da se identifikuju uzroci i alternative za izlazak iz zone gubitka preduzeća registrovanih na teritoriji Republike Srbije u sektoru A: Poljoprivreda, šumarstvo i ribarstvo (poljoprivredna preduzeća). Predmet istraživanja su finansijske performanse svih srednjih poljoprivrednih preduzeća u periodu 2010-2014. godina. Naglasak je na srednjim preduzećima iz razloga što ona, shodno učešću u ključnim makroekonomskim indikatorima, predstavljaju nosioce privredne aktivnosti u Republici Srbiji. Primenom metoda finansijske analize izvršena je ocena ekonomsko finansijske moći svih srednjih poljoprivrednih preduzeća u Republici Srbiji, a zatim su na primeru najneuspešnijih entiteta identifikovani uzroci i predložene alternative za izlazak iz zone gubitka. Rezultati istraživnja pokazuju da se gubitak javlja kao posledica smanjenja poslovnih prihoda, smanjenja marže pokrića i povećanja finansijskih rashoda. Za izlazak iz zone gubitka predlažu se dve alternative. Prva alternativa se odnosi na analizu mogućnosti povećanja obima proizvodnje i prodaje pri postojećem globalnom paritetu cena, dok druga alternativa podrazumeva analizu mogućnosti pomeranja globalnog pariteta cena u korist prodajnih cena pri postojećem stepenu iskorištenja realnog kapaciteta, odnosno pri postojećem obimu proizvodnje $i$ prodaje. $U$ istraživanju se polazi od hipoteze da implementacija predloženih alternativa doprinosi rastu profitabilnosti srednjih poljoprivrednih preduzeća. Performanse po osnovu čijih vrednosti je izmeren efekat implementacije predloženih alternativa su return on assets (ROA) i return on equity ( $R O E)$.
\end{abstract}

Key words: zona gubitka, poljoprivredna preduzeća, srednja preduzeća, finansijska analiza, ekonomsko finansijska moć

5 Dr, Naučni saradnik, Institut ekonomskih nauka, Zmaj Jovina 12, 11000 Beograd, Republika Srbija, Telefon: +381 63843 8896, E-mail: sonja.djuricin@ien.bg.ac.rs

6 Dr, istraživač saradnik, Institut ekonomskih nauka, Zmaj Jovina 12, 11000 Beograd, Republika Srbija, Telefon: +381 64145 5955, E-mail: isidora.beraha@,ien.bg.ac.rs

7 Dr, istraživač saradnik, Institut ekonomskih nauka, Zmaj Jovina 12, 11000 Beograd, Republika Srbija, Telefon: +381 64514 7136, E-mail: dusko.bodroza@ien.bg.ac.rs

EP 2018 (65) 1 (391-411) 